\title{
Effect of Topical Application of Hydro-Ethanolic Extract of Acacia nilotica Pods on Second-Degree Cutaneous Infected Burns
}

\author{
Kossi Metowogo ${ }^{1, *}$, Tchin Darré $^{1,2}$, François Daubeuf ${ }^{3}$, Povi Lawson-Evi ${ }^{1}$, \\ Kwashi Eklu-Gadegbeku', Kodjo A. Aklikokou', Gado Napo-Koura², \\ Nelly Frossard ${ }^{3}$ and Messanvi Gbeassor ${ }^{1}$
}

${ }^{1}$ Centre de Recherche et de Formation sur les Plantes Médicinales (CERFOPLAM), Laboratoire de Physiologie-Pharmacologie, Faculté des Sciences, Université de Lomé, Togo

${ }^{2}$ Laboratoire d'Anatomie et Cytologie Pathologiques, Faculté Mixte de Médecine et de Pharmacie, Université de Lomé, Togo

${ }^{3}$ UMR 7200, Laboratoire d'Innovation Thérapeutique, Equipe Chimie Biologie intégrative, Faculté de Pharmacie, Université de Strasbourg, Illkirch, France

\begin{abstract}
Acacia nilotica is a medicinal plant used traditionally in Togo to treat various diseases including burn wounds. The aim of this study was to evaluate experimentally Acacia nilotica burn wound healing effect.

Cutaneous burn wounds were symmetrically caused on depilated areas of rat skin through contact with an aluminum bar $(r=10 \mathrm{~mm})$, preheated at $80^{\circ} \mathrm{C}$ for $30 \mathrm{sec}$. Five groups of animal were constituted and each group contained 8 mice. Four groups of animal's burn wounds were infected by Staphylococcus aureus. One group burn wound is uninfected and serves as negative control. Burn wounds were assessed by planimetry and histological parameters of healing. Twelve days after burn wound induction, wound contraction in the uninfected groups (negative control) was 19.9\% for topical application against $-2.43 \%$ for infected control. In the infected groups treated with extract, wound contraction was generally stimulates. Histological examination showed granulated tissue developing over the wounds treated with the extract of $A$. nilotica at $2.5 \%$ and $5 \%$ where the proliferation of fibroblasts and neo-blood vessels was very marked.

In conclusion, $A$. nilotica pod contents tannin, flavonoids, alkaloids and protein reduces DPPH solution and significantly accelerates wound healing of burns, and this is the case even if wounds are infected with $10^{9} \mathrm{CFU} / \mathrm{mL}$ of $S$. aureus.
\end{abstract}

Keywords: Burns wound, A. nilotica, histology, wound infection, wound healing.

\section{INTRODUCTION}

The skin is the largest organ of the body with the purpose to serve as a barrier against external agents like micro-organism and chemical substance. The loss of skin tissue integrity may cause lesions or illnesses that can lead to death [1] because disruption of the skin generally increases fluid loss, infection, hypothermia, scarring, compromised immunity and change in the body image. The mortality rate from burns has declined in the past decade; however, it is still high, if more than $70 \%$ of the body surface is injured or burned [2]. Burns are classified according to lesion severity (depth of the injury) into superficial or first degree, when lesion is restricted to the epidermis or skin causing redness; partial thickness or second degree that can be superficial when reaching the epidermis and superficial dermis, showing hypersensitivity and pain, or deep when it extends to the deepest layer of the dermis and may have reduced sensitivity with red and/or white coloration of the tissue; full-thickness or third degree when lesion involves the subcutaneous layer, with no sensitivity and white coloring [3]. In superficial second-

*Address correspondence to this author at the Centre de Recherche et de Formation sur les Plantes Médicinales (CERFOPLAM), Laboratoire de Physiologie-Pharmacologie, Faculté des Sciences, Université de Lomé, Togo; Tel: 0022890946566; E-mail: kossi.metowogo@gmail.com

ISSN: 2223-3806 / E-ISSN: 1927-5951/15 degree burns, burns are very painful and generally caused by thermal injuries. Burn and trauma wounds are very common in both developed and developing countries; however, in developing countries, burn constitutes a major health problem because the incidence of severe complications like infections is high and financial resources are limited [4]. Infected burns wound cicatrization is generally complicated. The use of traditional medicinal plants in the treatment of burn wounds are an important aspect of health treatment and at the same time a way to reduce the financial burden. Among several plants used as traditional healing remedies in Togolese folk medicine, pods of $A$. nilotica have been reported. In order to revalorize use of medicinal plants, we had early demonstrated uninfected burns wound properties of $A$. nilotica pods extract [5]. This study was conducted to investigate the action of hydro-ethanolic extract of $A$. nilotica pods on second-degree infected burns in mice.

\section{MATERIAL AND METHODS}

Material

Plant Material

A. nilotica pods were purchased at Tsevie market (35 km north of Lomé) and taken to the herbarium of 
the Laboratory of Botany of University of Lome-Togo where they were authenticated (voucher specimen: $n^{\circ}$ Togo 04824/ Togo 04822/ Togo 04821). Pods were washed in water, freeze-dried and reduced to powder. To this powder $(1980 \mathrm{~g})$, was added $4 \mathrm{~L}$ of hydroethanolic solution (3:1). The mixture is stirred for 72 hours under manual intermittent then filtered. The filtrate was evaporated on Rota vapor (Buchi R-210) and the obtained extract was mixed to the gel for the tests.

\section{Animals}

ICR mice (30-35 g weight) purchased from Nogoschi Memorial Medical Research Institute of The University of Ghana were used for this study. They were housed for 10 days at Laboratoire de Physiologie Animale of Université de Lomé (Togo) for acclimatization. They were maintained on standard experimental conditions of temperature, $12 \mathrm{~h}$ light/dark cycle and fed on normal pallet diet, and water allowed ad libitum throughout the experiment. Except the agents under study, no topical or systemic therapy was given to animals.

Five groups of animal were constituted and each group contained 8 mice. Group -I burn's wound are uninfected and serves as negative control receiving Carbopol empty gel. Three days after burns created, wounds of the fours last group were infected by Staphylococcus aureus. $10^{9} \mathrm{CFU} / \mathrm{mL}$ of Staphylococcus solution were used and $100 \mu \mathrm{L}$ of this solution is inoculated in the wounds. Group II serves as positive control, and then his burn wound is treated by Carbopol empty gel. Groups-III and IV were locally applied with Carbopol gel containing $2.5 \%$ and $5 \%$ of $A$. nilotica pods extract respectively. Group- $V$ received the standard treatment with Brulex® (Baily-Creat, France).

\section{Methods}

\section{Qualitative Phytochemical Analysis}

Phytochemical screenings of the extract were carried out to identify the chemical constituents like tannins, flavonoids, saponosids, alkaloids, polysaccharides and protein using standard phytochemical methods. Dragendoff and Mayer's essays were done to determine the presence of alkaloids, 5\% Fecl3 solution and 10\% lead acetate were used to identify tannins, $5 \% \mathrm{FeCl} 3$ and $10 \%$ $\mathrm{NaOH}$ solution to determine flavonoids presence in extract. Identification of Polysaccharides was evaluated by Mollish test and Protein presence by using Biuret test.

\section{Quantitative Determination of Total Phenolic and Flavonoids}

\section{Total Phenolic Content}

The amount of phenol in the aqueous extract was determined by Folin-Ciocalteu reagent method with some modifications. $60 \mu \mathrm{L}$ of $10 \%$ Folin-Ciocalteu reagent and $120 \mu \mathrm{L}$ of $2 \%$ solution of $\mathrm{Na}_{2} \mathrm{CO}_{3}$ were added to $60 \mu \mathrm{L}$ of plant extract. The resulting mixture was incubated for 30 minutes at room temperature. The absorbance of the sample was measured at 760 $\mathrm{nm}$. Gallic acid was used as standard $(200 \mu \mathrm{g} / \mathrm{ml})$. All the tests were performed in triplicates. The results were determined from the standard curve and were expressed as Gallic acid equivalent (mgGAEq/g of extracted compound).

\section{Total Flavonoid Content}

Aluminium chloride colorimetric method was used with some modifications to determine flavonoid content. $20 \mu \mathrm{L}$ of sample plant extract was mixed with $70 \mu \mathrm{L}$ of ethanol $95^{\circ}, 10 \mu \mathrm{L}$ of $10 \%$ aluminium chloride, $10 \mu \mathrm{L}$ of $1 \mathrm{M}$ sodium acetate and $140 \mu \mathrm{L}$ of distilled water and remains at room temperature for 30 minutes. The absorbance was measured at $415 \mathrm{~nm}$. Quercetin was used as standard $(0.8 \mathrm{mg} / \mathrm{ml})$. All the tests were performed in triplicates. Flavonoid contents were determined from the standard curve and were expressed as quercetin equivalent (mgQEq/g of extracted compound).

\section{DPPH Essay}

To evaluate radical scavenger effect of extract, DPPH essay was performed. About $100 \mathrm{mmol} / \mathrm{l}$ solution of DPPH (2mg of DPPH) in $100 \%$ methanol $(50 \mathrm{ml})$ was prepared and $200 \mu \mathrm{L}$ of this solution was added to $10 \mu \mathrm{L}$ of the extract dissolved in methanol at different concentrations. The mixture was shaken and allowed to stand at room temperature for $30 \mathrm{~min}$ and the absorbance was measured at $517 \mathrm{~nm}$ using spectrophotometer. Inhibition percentage [I (\%)] was calculated as follow: I $(\%)=(\mathrm{A} 0-\mathrm{At}) / \mathrm{A} 0 \times 100$, where $A 0$ is the absorbance of the control and at is the absorbance of the test compound. IC50 value (concentration of sample which reduced $50 \%$ of DPPH) was determined from inhibition percentage curve according to the concentration. The IC50 value of the extract was compared with that of ascorbic acid, which was used as the standard.

\section{Preparation of Gels}

The gel was prepared as follows: $0.3 \mathrm{~g}$ of Carbopol 974P NF (Goodrich, USA) was dispersed in $27 \mathrm{~g}$ of 
distilled water and mixed by stirring continuously on a magnetic stirrer (IKA-Combimag RCT) at $800 \mathrm{rpm}$ for 1 h. The mixture under continuous stirring was neutralized by drop-wise addition of $\mathrm{NaOH} 1 \mathrm{~mol} / \mathrm{l}$. Mixing was continued until a transparent gel was formed [6, 7]. Three types of gel formulations were prepared: empty gel, gel containing $2.5 \%$ and $5 \%$ of $A$. nilotica pods extract. For standard treatment we used dermal Brulex ${ }^{\circledR}$ reference drugs.

\section{Burn Wound Induction}

Mice were anesthetized by the open mask method with diethyl ether and their dorsal surface was shaved by using a shaving machine. Burns were symmetrically caused on depilated areas through contact with an aluminum bar $(r=10 \mathrm{~mm})$, preheated at $80 \circ \mathrm{C}$ for 30 sec. The bar is maintained in contact with the animal skin on the dorsal proximal region for $20 \mathrm{sec}$, immediately after the procedure of burn wound induction, A. nilotica pods extract on carbopol gel or Brulex ${ }^{\circledR}$ was applied topically. The wounds were left undressed to the open environment and observed daily. The treatments were applied topically once a day, starting from the wound induction until day 12 post-excision.

\section{Burn Wound Infection}

Wounds were infected by Staphylococcus aureus obtained from Laboratory of Microbiology and food hygiene of Université de Lomé on the $3^{\text {rd }}$ day after burn induction according to the method of Kumar et al. (2008) [8] after slight modification. Briefly, Bacterial culture is made based bacterial strains of Staphylococcus aureus obtained in the Laboratory of Microbiology, Université of Lome. A bacterial suspension was made from the liquid LB medium at $37^{\circ} \mathrm{C}$ and cultured for 16 hours to ensure that the density reaches $10^{\circ} \mathrm{CFU} / \mathrm{ml}$. An aliquot $(100 \mu \mathrm{L})$ of each bacterial inoculation was incubated at $37^{\circ} \mathrm{C}$, and then wounds were infected on the third day post burn wounds.

\section{Measurement of Wound Area}

The progressive changes in wound area were monitored by a camera (Pentax, Option E75, and
China) every other third day. Later on, wound area was evaluated by using Image $J$ program. Wound contraction (WC) was calculated as a percentage of the reduction in wound area by using the mathematic expression: $\mathrm{WCd}=(1-\mathrm{WAd} / \mathrm{WA} 0) \times 100$ where WAd is the area of the wound on the day $d$ and WAO the wound area on day $0[7,9]$.

\section{Histological Studies}

After wound area was measured, animals were killed under ether anesthesia and immediately skin samples from the wounds in each group were collected on day 8 for tree mice and day 12 for the rest. The specimens were fixed in $10 \%$ neutral buffered formalin, processed and included in paraffin. Five-micrometer skin sections were cut and stained with hematoxylineosin [10]. The tissues were qualitatively assessed under light microscopy (Olympus BX 51) at 200x or 400x magnification and graded as absent $(-)$, mild $(+)$, moderate $(++)$ and severe $(+++)$ for epidermal or dermal remodeling. Epithelialization, ulceration and necrosis in epidermis, congestion edema, fibroblast proliferation, mononuclear and polynuclear cells and neovascularization in dermis were analyzed [11].

\section{Statistical Analysis}

Results are reported as means \pm standard errors. The statistical significance between values in the treated groups and controls was evaluated with a one way ANOVA followed by Bonferroni's multiple comparison tests. $P$ values less than 0.05 were considered to be statistically significant.

\section{RESULTS}

\section{Qualitative and Quantitative Phytochemical Analysis Results}

Phytochemical analysis using standard colorimetric methods revealed presence of tannin, flavonoid, alkaloids and proteins. Folin-ciocalteu methods used permits to determine the amount of polyphenols in the extract. $182.49 \pm 5.19 \mathrm{mg} \mathrm{GAEq} / \mathrm{g}$ of extract compound of polyphenols was in the extract. $12.8 \pm 1.33 \mathrm{mg}$

Table 1: Amount of Polyphenols and Flavonoids in A. nilotica Pods Extract and his Antioxidants Activity

\begin{tabular}{|c|c|c|c|}
\hline & $\begin{array}{c}\text { Polyphenols } \\
(\mathbf{m g ~ G A E q} / \mathbf{g} \text { of extract) }\end{array}$ & $\begin{array}{c}\text { Flavonoids } \\
(\mathbf{m g} \mathbf{Q E q} / \mathbf{g} \text { of } \text { extract })\end{array}$ & $\begin{array}{c}\text { DPPH Essay } \\
\mathbf{I C}_{\mathbf{5 0}}(\boldsymbol{\mu g} / \mathbf{m L})\end{array}$ \\
\hline \hline A. nilotica Pods hydroalcoholic extract & $182.49 \pm 5.19$ & $12.8 \pm 1.33$ & 63.20 \\
\hline Ascorbic acid & & & 80.33 \\
\hline
\end{tabular}

$\mathrm{mg} \mathrm{GAEq/g:} \mathrm{milligram} \mathrm{gallic} \mathrm{acid} \mathrm{equivalents/gram.}$

$\mathrm{mg} \mathrm{QEq} / \mathrm{g}$ : milligram quercetin equivalents/gram. 
QEq $/ \mathrm{g}$ of extract compound of flavonoids was determined in the extract (Table 1).

\section{Radical Scavenger Activity}

A. nilotica pods hydroalcoholic extract possess radical scavenger properties. This extract reduces DPPH solution by discoloring rose color to yellow. $\mathrm{IC}_{50}$ value of extract is $63.20 \mu \mathrm{g} / \mathrm{ml}$ vs $80.33 \mu \mathrm{g} / \mathrm{ml}$ for ascorbic acid (Table 1).

\section{Burn Wound Healing Effect}

Topical application of gel of $A$. nilotica pods extract at $5 \%$ and $2.5 \%$ enhances cutaneous burn wounds healing by stimulating wound contraction. This was observed macroscopically with increased contraction of the wound in mice topically treated with $A$. nilotica extract gel as compared to controls. Wound contraction is one parameter used to assess wound healing. Significant wound contraction was initiated from day 4 in treated groups versus positive controls (infected control). Comparison between negative control (GroupI: uninfected) and positive control (Group-II: infected) wound contraction values showed that infection of burn wound delayed wound healing. Wound contraction for Group-I, $4^{\text {th }}, 8^{\text {th }}$ et $12^{\text {th }}$ days of experiment is respectively $9.65 \pm 0.65,14.85 \pm 0.34,16.55 \pm 0.94$ against $-9 \pm 0.5,-8.5 \pm 0.5,-2.43 \pm 0.43$ for Group-II. Comparison between treated groups (Group III and IV treated respectively by $A$. nilotica gel at $2.5 \%$ and $5 \%$ ) and Group I on day 12 show that extract inhibits staphylococcus proliferation and promote wound healing. For example wound contraction for group I on day 12 is $16.55 \pm 0.94$ against $15.35 \pm 0.34$ and $16.5 \pm$ 0.5 respectively for Group III and IV (Figure 1).

\section{Histological Studies}

Histological sections performed for uninfected control (Group-I)and treated groups (Group- III, IV, V) on day 8 after induction of burn show epidermal ulceration and the presence of necrotic tissue debris interspersed with inflammatory cells with polymorphic congestion and edema of the dermis in control mice. In infected control (Group-II) we noted exacerbation of necrosis, congestion, edema and proliferation of inflammatory cells. On day 12 after induction of burn, histological sections for uninfected group show in control mice, a low epithelialization of epidermal ulceration in some mice (Figure 2A). It was still a polymorphic inflammatory infiltrate in the dermis with edema, witness of an incomplete healing. By contrast, in infected mice by day 12 after induction of burn,

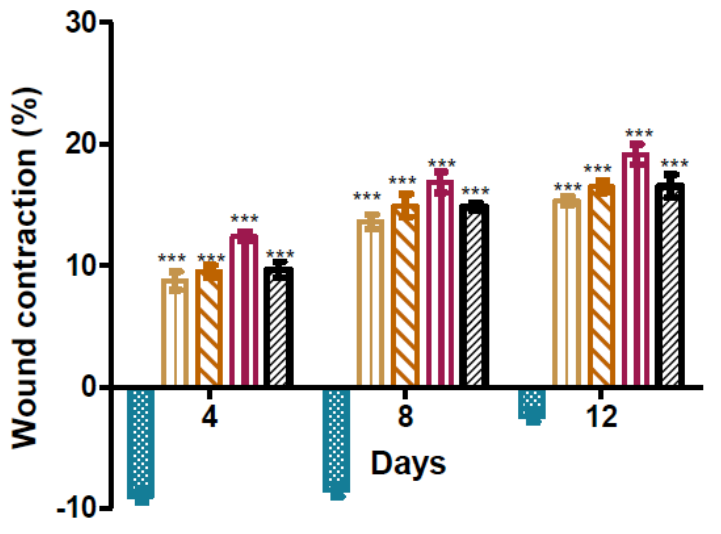

Control infected

A. nilotica $2.5 \%$

$\square$ A. nilotica $5 \%$

m Brulex®

(20) Control uninfected

Figure 1: Effect of topical application of A. nilotica pods on infected cutaneous burn wound.

Wound contraction was expressed as percentage of wound closure using wound area on day d compared with wound area on the first day. Results are expressed as means \pm SEM of $n=8$ mice per group. ${ }^{* \star *}$ indicates $p<0.001$ for the treated groups as compared with controls.

histological sections for control (Figure 2B) show epidermal ulceration, polymorphic inflammatory infiltrate in the dermis with edema. In groups of mice treated with the extract of $A$. nilotica2.5, $5 \%$ and (Brulex $\AA$ (respectively Figure 2C, 2D and 2E), an early epithelialization was observed with hair follicles and fibroblastic elements, despite the infection (Table 2).

\section{DISCUSSION}

Burns remain a huge public health issue, at least in terms of morbidity and long term disability, throughout the world, especially in the developing countries [12]. Burn wound healing is a complex process characterized by re-epithelialization and formation of granulated tissue and remodeling of the extracellular matrix. It causes discomfort and is prone to infection, a major complication of burn injury responsible for 50 $75 \%$ of hospital deaths [13]. Though healing process takes place by itself and does not require much help, various risk factors such as infection and delay in healing have brought attention to promote this process. The results obtained show that topical application of $A$. nilotica extract gel at the wound site produces significant wound healing activity, by 1 ) its capacity to promote wound contraction, 2) formation of granulated tissues and 3) re-epithelialization in infected burn wounds. We first show that uninfected burn wound contraction was increased in animals treated with 

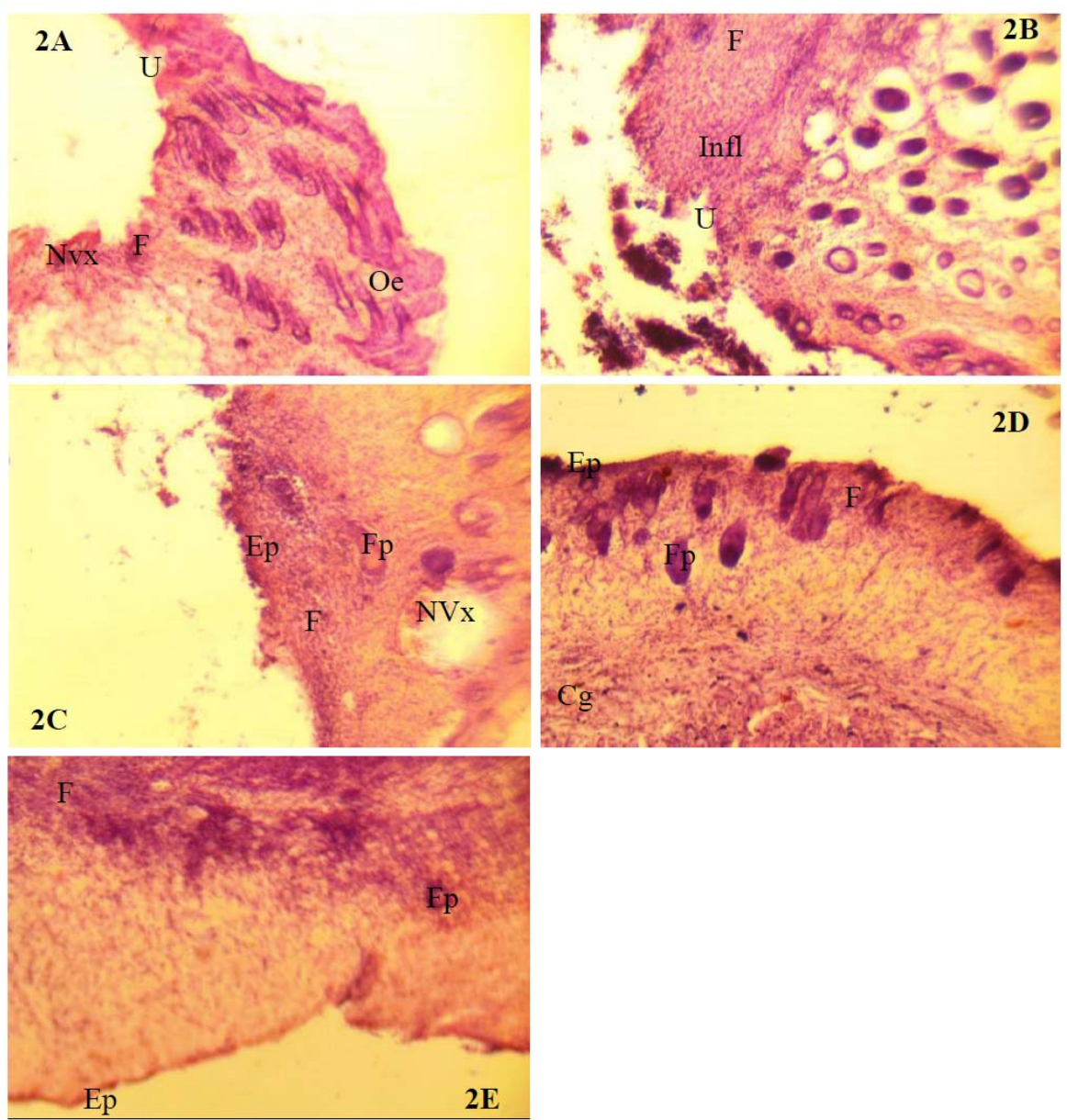

Figure 2: Histological sections of wounded skin treated topically with the vehicle alone (Carbopol empty gel), A. nilotica pods extracts at 2.5 and $5 \%$, and Brulex® on D12.

Uninfected group (A: control; B, C; D: treated respectively by A. nilotica 2.5, 5\% and Brulex), Infected group (E: control; F, G, H: treated respectively by $A$. nilotica $2.5,5 \%$ and Brulex)U: ulceration; Oe: edema; Infl: presence of inflammatory cells; Cg: congestion; Ep: epithelialization; Fp: hair follicle; F: fibroblast proliferation; NVx: congestive vessels of the dermis. (Hematoxylineosin staining, $\mathrm{x} 100)$.

Table 2: Histological Evaluation of Wound Healing Process of of A. nilotica Gel and Brulex® on Burn Wound

\begin{tabular}{|c|c|c|c|c|c|c|c|c|c|}
\hline Traitement & C & Ed & PMN & MNC & $\mathbf{N}$ & FP & NV & Ep & $\mathbf{U}$ \\
\hline Uninfected control & + & + & ++ & ++ & - & + & ++ & ++ & + \\
\hline Infected control & ++ & ++ & ++ & ++ & - & - & +++ & + & ++ \\
\hline A. nilotica $2,5 \%$ & ++ & + & + & + & + & + & + & ++ & + \\
\hline A. nilotica $5 \%$ & ++ & + & + & + & - & + & + & ++ & + \\
\hline Brulex® & + & + & + & + & - & ++ & + & ++ & + \\
\hline
\end{tabular}

A. niloticageland Brulex® were administrated topically an infected burn wound once per day during the 12.post burn wound days.

Hematoxilin-eosin stained sections were scored as mild (+), moderate (++) and severe (+++) for epidemal and/or dermal remodeling. Epithelialization and ulceration were scored as present $(+)$ and absent (-). C: congestion; Ed: edema; PMN: polymorphonuclear cells; MNC: mononuclear cells; N: necrosis; FP: fibroblast proliferation; NV: neovascularization; Ep: epithelialization; U: ulceration.

A. nilotica [5], as visualized by the method described by Amegbor et al. (2012) [7]. According to this method wound contraction or wound closure was determined by using the initial and final areas monitored by camera and evaluated by Image $J$ programme during the experiments, with percentage wound closure calculated as [(initial—final)/initial] $\times 100$. Similarly, formation of granulated tissue was also increased in burn wound healing treated with $A$. nilotica as compared with controls treated with carbopol gel alone. Epithelialization also was increased in $A$. nilotica treated group than controls. The prohealing activity was marked as all the parameters observed were significantly affected. 
A. nilotica extract gel accelerates uninfected [5] or infected burn wound healing. As reported by Kumar et al. (2006) [14] and Peraira et al. (2012) [15], burn wounds were usually infected by bacteria gram positive like $S$. aureus and this infection delays wound healing. The significant burn wound healing effect of $A$. nilotica extract observed in the infected group associates with delay wound healing observed after wound infection by staphylococcus aureus in controls indicating that $A$. nilotica pods extract are responsible for an effective antimicrobial activity. This confirms the findings by Arias et al. 2004 [16] and Al-Fatimi et al. 2007 [17] demonstrating antimicrobial effect of $A$. nilotica on gram-positive bacteria.

Extract compounds are responsible of wound healing and antimicrobial effect. Our study demonstrated that extract contained polyphenols. We have also demonstrated extract have radical scavenger activity. Radicals scavenger contributes to accelerate wound healing.

\section{CONCLUSION}

Topical application of gel containing $A$. nilotica extract exhibited significant prohealing activity in burn wound on mice by affecting various stages of healing process. The result of the present study offers pharmacological evidence on the folkloric use of $A$. nilotica pods for healing wounds.

\section{REFERENCES}

[1] Jorge MP, Madjarof C, Ruiz ALTG, Fernandes AT, Rodrigues RAF, Sousa IMO, Foglio MA, Ernesto De Carvalho J. Evaluation of wound healing properties of Arrabidaeachica Verlot extract. J Ethnopharmacol 2008; 118: 361-366. http://dx.doi.org/10.1016/j.jep.2008.04.024

[2] Alemdaroglu C, Degim Z, Celebi N, Zor F, Ozturkand S, Erdogan D. An investigation on burn wound healing in rats with chitosan gel formulation containing epidermal growth factor. Burns 2006; 32: 319-327. http://dx.doi.org/10.1016/j.burns.2005.10.015

[3] Pereira DST, Lima-Ribeiro MHM, Nicodemos TPF, CarneiroLeao AMA, Correia MTS. Development of Animal Model for Studying Deep Second-Degree Thermal Burns. J Biomed Biotechnol 2012a; 2012: 7 p. http://dx.doi.org/10.1155/2012/460841

[4] Gurung S, Skalko-Basnet N. Wound healing properties of Carica papaya latex: In vivo evaluation in mice burn model. J Ethnopharmacol 2009; 121: 338-341. http://dx.doi.org/10.1016/j.jep.2008.10.030

[5] Darré T, Metowogo K, Lawson-Evi P, Eklu-Gadegbeku K, Aklikokou AK, Napo-Koura G, Gbeassor M. Effet topique de l'extrait hydro-ethanolique de l'acacia nilotica sur la cicatrisation cutanée des brulures de second degre. European Scientific Journal 2014; 10: 1857-7881.

[6] Trombetta D, Puglia C, Perri D, Licata A, Pergolizzi S, De Pasquale A, Saija A, Bonina FP. Effect of polysaccharides from Opuntiaficus-indica (L.) clatodes on the healing of dermal wounds in the rat. Phytomedicine 2006; 13: 352-358. http://dx.doi.org/10.1016/j.phymed.2005.06.006

[7] Amegbor K, Metowogo K, Eklu-Gadegbeku K, Agbonon A Aklikokou AK, Napo-Koura G, Gbeassor M. Preliminary evaluation of the wound healing effect of vitexdonianasweet (verbenaceae) in mice. Afr J Tradit Complement Altern Med 2012; 9: 584-590.

http://dx.doi.org/10.4314/ajtcam.v9i4.16

[8] Kumar MS, Kirubanandan S, Sripriya R, Sehgal PK. Triphala Promotes Healing of Infected Full-Thickness Dermal Wound. J Surg Res 2008; 144: 94-101. http://dx.doi.org/10.1016/j.jss.2007.02.049

[9] Sadaf F, Saleem R, Ahmed M, Ahmadand SI, Navaid-UI Z. Healing potential of cream containing extract of Sphaeranthusindicius on dermal wounds in Guinea pigs. $J$ Ethnopharmacol 2006; 107: 161-163. http://dx.doi.org/10.1016/i.jep.2006.02.022

[10] Mcmanus JFA, Mowry RW. Stanning methods, histologic and histochemical. Haper Raw, New York, Evanston, Lodon 1965.

[11] Akkol EK, Koca U, Pe Sin I, Yilmazer D, Tokerand G, Yesilada E. Exploring the wound healing activity of Arnebiadensiflora (Nordm.) Ledeb by in vivo models. $J$ Ethnopharmacol 2009; 124: 137-141. http://dx.doi.org/10.1016/j.jep.2009.03.019

[12] Priya KS, Gnanamani A, Radhakrishnan N, Babu M. Healing potential of Datura alba on burn wounds in albino rats. $J$ Ethnopharmacol 2002; 83: 193-199. http://dx.doi.org/10.1016/S0378-8741(02)00195-2

[13] Mokaddas EVO, Sanyal SC. In vitro activity of piperacillin/tazobactam versus other broad antibiotics against nosocomial gram negative pathogens isolated from burn patients. J Chemotherapy 1998; 10: 208-214. http://dx.doi.org/10.1179/joc.1998.10.3.208

[14] Kumar MS, Kirubanandan S, Sripriya R, Raghavan HV Sehgal PK. Wound Healing Potential of Cassia fistula on Infected Albino Rat Model. J Surg Res 2006; 131: 283-289. http://dx.doi.org/10.1016/j.jss.2005.08.025

[15] Pereira DST, Lima-Ribeiro MHM, Santos-Oliveira R Cavalcanti CLB, Teles De Pontes-Faldo N, Coelho LCBB, Carneiro-Leao AMA, Correia MTS. Topical Application Effect of the Isolectin Hydrogel (Cramoll 1,4) on Second-Degree Burns: Experimental Model. J biomed biotechnol 2012b; 2012: $11 p$. http://dx.doi.org/10.1155/2012/184538

[16] Arias ME, Gomez JD, Cudmani NM, Vattuone MA, Isla MI Antibacterial activity of ethanolic and aqueous extracts of Acacia aroma Gill. ex Hook et Arn. Life Scie 2004; 75: 191202.

http://dx.doi.org/10.1016/j.lfs.2003.12.007

[17] Al-Fatimi $M$, Wurster $M$, Schroder $G$, Lindequist $U$. Antioxidant, antimicrobial and cytotoxic activities of selected medicinal plants from Yemen. J Ethnopharmacol 2007; 111: 657-666.

http://dx.doi.org/10.1016/i.jep.2007.01.018 